\title{
IMPROVED REVERSE ARITHMETIC-GEOMETRIC MEANS INEQUALITIES FOR POSITIVE OPERATORS ON HILBERT SPACE
}

\author{
Hongliang ZUO AND NAN CHENG
}

\begin{abstract}
In this paper, employing induction on the given reverse Young inequalities, we obtain more reverse arithmetic-geometric means inequalities for two positive operators. Concretely, following the main result from [13] we obtain reverse ratio type inequalities and reverse difference type inequalities of the refined arithmetic-geometric means inequality for two positive operators on a Hilbert space.
\end{abstract}

Mathematics subject classification (2010): 47A30, 47A63.

Keywords and phrases: Jensen operator, reverse arithmetic-geometric means, Jensen's functional.

\section{REFERENCES}

[1] J. BARIĆ, M. Matić And J. PeČARIĆ, On the bounds for the normalized Jensen functional and Jensen-Steffensen inequality, Math. Inequal. Appl., 12, 2(2009), 413-432.

[2] S. FurUichI, On refined Young inequalities and reverse inequalities, J. Math. Inequal., 5, 1 (2011), 21-31.

[3] O. Hirzallah, F. Kittaneh, M. Krić, N. LovričEvić, J. PeČArić, Refinements and reverses of means inequalities for Hilert space operators, Banach J. Math. Anal., 7, 2 (2013), 15-19.

[4] F. KitTANEH, Reverse Young inequalities for matrices, Linear Multilinear Algebra, 59, 9 (2011), 1031-1037.

[5] F. Kittaneh And Y. ManasRah, Improved Young and Heinz inequalities for matrices, J. Math. Anal. Appl., 36, 1 (2010), 262-269.

[6] M. Klarić Bakula, J. Pečarić and J. Perić, On the converse Jensen inequality, Appl. Math. Comput., 218, (2012), 6566-6575.

[7] M. KRnić, N. LovriČEviĆ, AND J. PeČARIĆ, Improved arithmetic-geometric and Heinz means inequalities for Hilbert space operators, Publ. Math. Debrecen, 80, (2012), 3-4.

[8] M. KRnić, N. LOVRIČEVIĆ AND J. PEČARIĆ, Jensen's operator and applications to mean inequalities for operators in Hilbert space, Bull. Malays. Math. Sci. Soc., 35, 1 (2012), 1-14.

[9] F. Kubo And T. Ando, Means of positive operators, Math. Ann., 246, 3 (1980), 205-224.

[10] J. PEČARIĆ AND P. R. BEESACK, On Jensen's inequality for convex functions II, J. Math. Anal. Appl., 118, (1986), 125-144.

[11] W. SPEChT, Zer Theorie der elementaren Mittel, Math. Z., 74, (1960), 91-98.

[12] M. Tominaga, Specht's ratio in the Young inequality, Sci. Math. Japon., 55, 3 (2002), 583-588.

[13] H. L. Zuo, M. FujII, J. I. FujII AND Y. SEO, Upper bound for spectra of Jensen operator and its application to reverse arithmetic-geometric means, Math. Inequal. Appl., 17, 2 (2014), 641-648.

[14] H. L. Zuo, G. H. SHI AND M. FujII, Refined Young inequality with Kantorovich constant, J. Math. Inequal., 5, 4 (2011), 551-556. 